海の研究(Oceanography in Japan), 23(1), 1-12, 2014

一 論 文 -

\title{
諫早湾調整池から排水された 高濁度水の湾内における短期的な挙動の解明*
}

小森田 智大 ${ }^{1} \cdot$ 梅原 亮 ${ }^{1} \cdot$ 田井 明 ${ }^{2} \cdot$ 高橋 $_{\text {徹 }}^{3}$ - 堤 裕昭 $^{1}$

要 旨

諫早湾潮受け堤防からの排水の挙動を捉えるために, 諫早湾内に 9 定点を設け, 2012 年 9 月 18 日から 19 日にかけて合計 6 回の高頻度観測を実施した。調整池の懸濁粒子（SS） および懸濁態有機炭素 $(\mathrm{POC})$ 濃度に排水量 $\left(2.3 \times 10^{6} \mathrm{~m}^{3}\right)$ を乗じて算出した排出量は $326 \times 10^{6} \mathrm{~g}(\mathrm{SS})$ および $13.3 \times 10^{6} \mathrm{~g}(\mathrm{POC})$ と見積もられた。一方，これらの排出量は，排 水後の排水門近傍における増加量の $16 \%$ ならびに $25 \%$ に過ぎず, 排水時には堆積物の再 懸濁が顕著である可能性が示された。水柱の SS および POC 濃度の時間変化とストーク スの最終沈降速度をもとに検討したところ，SS こついては少なくとも水柱に 3 時間懸濁 したことから, $10 \mu \mathrm{m}$ より小さい粒子が主であり, POC は排水から 3 時間後には濃度が 排水直後の 2 割程度にまで低下したことから, POC の約 8 割が沈降により水柱から除去 される大型の粒子 (粒径: $10 \mu \mathrm{m}$ 以上) であった可能性が高い。炭素安定同位体比の観測 結果によると, 排水から 3 時間後, 排水門近傍の水柱に残された POC の 8 から 10 割が調 整池由来の有機物であることが示された。さらに，排水から 21 時間後には，湾内に低塩 分水のパッチが観測されなかったことから，粒径が $10 \mu \mathrm{m}$ 未満の小型粒子は下げ潮時に 湾外へと流出する可能性が示唆された。

キーワード：諫早湾，高濁度水，懸濁粒子

\section{1.はじめに}

九州西岸の有明海に位置する諫早湾の奥部には, 諫早 湾干拓事業により潮受け堤防が建設された。諫早湾干拓 事業が着工された 1990 年以降, 有明海奥部海域ではア

\footnotetext{
* 2013 年 5 月 23 日受領; 2013 年 7 月 30 日受理 著作権：日本海洋学会, 2014

1 熊本県立大学環境共生学部 $\bar{T} 862-8502$ 熊本市東区月出 $3-1-100$

2 九州大学高等研究院 $=819-0395$ 福岡市西区元岡744番地

3 熊本保健科学大学保健科学部 $=861-5598$ 熊本市北区和泉町325 連絡著者：小森田 智大 TEL：096-321-6718

e-mail : komorita@pu-kumamoto.ac.jp
}

サリやタイラギをはじめとする魚介類の減少や，赤潮の 大規模化・長期化（堤ら, 2003), および貧酸素発生域 の拡大（堤ら, 2007）などが深刻な社会問題に発展して いる。1997 年の潮受け堤防の締め切りによって, 諫早 湾奥部の 3,500 ha の水域が淡水化し, 内部の生物層に 大きな変化をもたらし（佐藤, 2000), 水質については 全窒素や全リン濃度が 3 から 4 倍程度上昇した（佐々 木, 2005)。さらに, 淡水化した調整池の内部では有毒 藍藻類である Microcystis sp. が大規模なブルームを起こ し，有毒物質である Microcystin が生産されている (Umehara et al., 2012)。潮受け堤防内の調整池では, 堤防内の水位を海抜一 $1 \mathrm{~m}$ の高さに調節するために, 
干潮時に 2 力所の排水門を通して諫早湾へと年間約 $4 \times 10^{8} \mathrm{~m}^{3}$ の淡水が排出されていることから（佐々木, 2005), 有毒物質の沿岸域への流出が懸念されている (Umehara et al., 2012)。潮受け堤防からの排水は，排 水門の近傍のみならず，諫早湾湾口部における表層流の 流動特性にも影響を与え（多田ら, 2007), 諫早湾奥部 から供給される物質は，有明海奥部海域へと供給される 可能性が高い（田井・小松, 2013）。このことから, 有 明海全域の海洋環境を総合的に捉えるためには，排水に よる影響の定量的評価が基礎的知見として必要である。

諫早湾干拓事業の影響が最も顕著であることが予想さ れる諫早湾においては，湾口部における潮流調査（中村 ら, 2002; 多田ら, 2007; 坪野ら, 2009; 田井ら, 2012), 溶存酸素濃度の高頻度観測（多田ら, 2007）や低塩分水 の分布 (多田ら, 2010; 齋田ら，2010)，湾全体の海水交 換（齋田ら，2006）, 堆積物の間隙水中おょび粒子吸着 態のアンモニア態窒素濃度の分布と物質循環への影響 (手塚ら, 2012), 海底堆積物の粒度組成および化学組成 （李・松永, 2010）について, 精力的に調査・研究が進 められてきた。諫早湾においては, 潮受け堤防からの排 水に伴い大量の懸濁物質が供給されると想定されるが (佐々木, 2005), 排水に関する現地調査の報告は限られ ている（多田ら，2010）。2010年 12 月，福岡高等裁判 所の判決により, 諫早湾干拓事業が諫早湾抒よびその近 傍を含む有明海の環境に及ぼす影響を解明するために,
諫早湾の潮受け堤防の中長期開門調査を実施することが 確定した。中長期間開門された場合に, 開門前後におけ る諫早湾ならびに有明海の環境変化を定量的に評価する ことは，有明海の海洋生態系を本質的に理解するための 重要な知見となる。

本研究では，中長期開門調査の前段階（2012 年 9 月） の諫早湾内において, 諫早湾潮受け堤防からの排水前後 に水温，塩分，懸濁粒子濃度（SS）, 懸濁態有機炭素濃 度 $(\mathrm{POC}), \mathrm{POC}$ の炭素安定同位体比 $\left(\mathrm{d}^{13} \mathrm{C}\right)$ につい ての面的観測を実施した。これらの結果をもとに，排水 門の近傍において, 淡水, SS および POC の増加量を推 定し，調整池のSS および POC 濃度を元に算出した調 整池からの理論的な排水量と比較することで，排水の特 徵を評価する。さらに, SS と POC の時間変化の違いを 比較するとともに, $\mathrm{d}^{13} \mathrm{C}$ に基づき調整池由来の粒状有 機物の寄与率を推定した。以上の結果をもとに, 調整池 から排水された高濁度水に含まれる SS および POC の 短期的（数時間〜 1 日スケール）な挙動について考察す る。

\section{2. 材料と方法}

\section{1 調査域}

諫早湾は有明海奥部海域の西部に位置する内湾であ

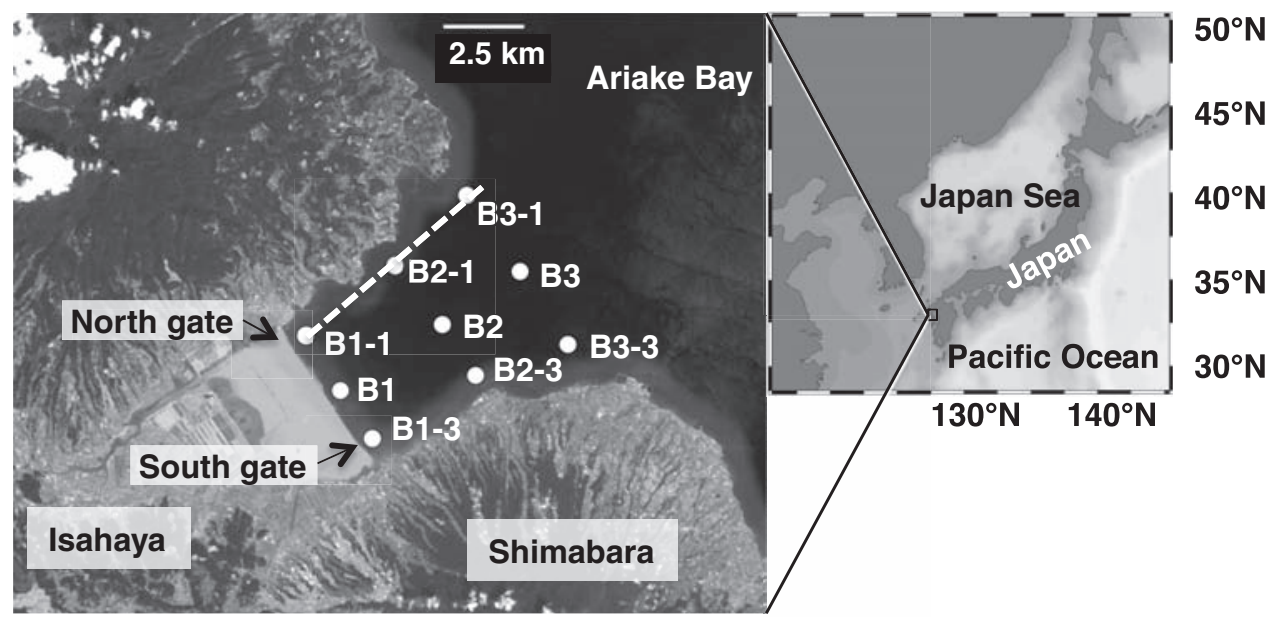

Fig. 1. Study area and sampling locations. The dashed line indicates the vertical transect. 
り, 調整池を除いた湾の面積は約 $65 \mathrm{~km}^{2}$ である（佐藤, $2000)$ 。平均水深は湾口部で $10 \mathrm{~m}$ であり, 大潮時の潮 位差は $5 \mathrm{~m}$ に達する。海抜一 $1 \mathrm{~m}$ の高さに水面を保つた めに, 調整池の水深は $1.5 \mathrm{~m}$ から $1.8 \mathrm{~m}$ に調整されてお り，排水は北部排水門と南部排水門のいずれかを通して 諫早湾へと排出される（Fig. 1)。今回調査を行った 2012 年 9 月に打いては，北門㧍よび南門からそれぞれ 2 回ならびに 9 回の合計 11 回排水されている (Fig. 2)。 本研究では北門から $2.3 \times 10^{6} \mathrm{~m}^{3}$ の排水があった 9 月 18 日から 19 日にかけて，9調査定点を設けて合計 6 回の高 頻度観測を実施した（Fig. 3）。

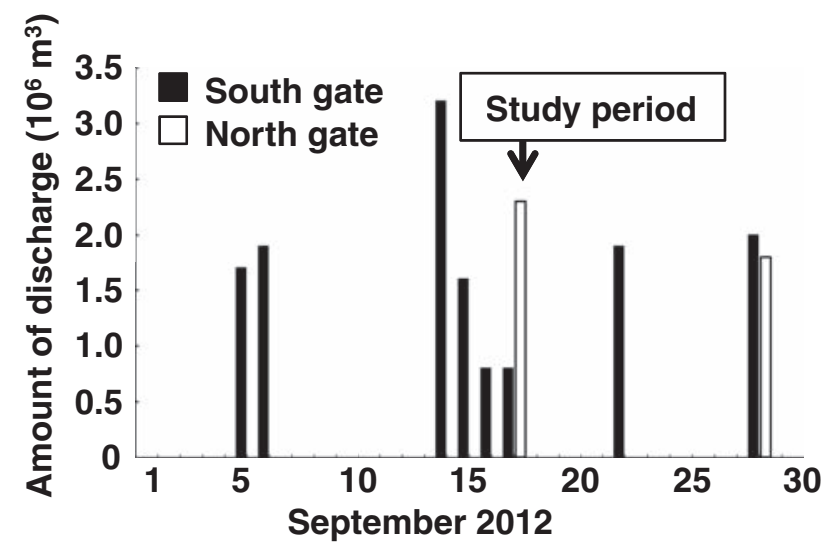

Fig. 2. Amount of fresh water discharged from north and south gates in September 2012.

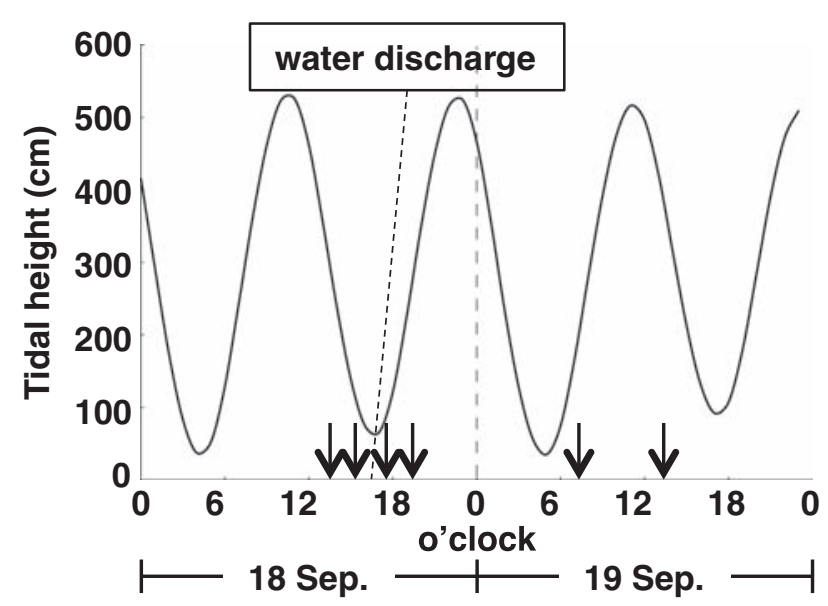

Fig. 3. Time series variation of the tidal height. Arrows indicate each sampling instance.

\section{2 調查方法}

調査は 2012 年 9 月 18 日から 19 日にかけて, 諫早湾 調整池から排水される前後に合計 6 回の面的観測を 2 隻 の調査船により行った。観測の直前（9月18日11 時） には, 排水される水質を特定するために, 北門の内側で 採水した。全測点に打いて, 多項目水質計（YSI 6600） を用いて, 水深に応じて 0.5 または $1 \mathrm{~m}$ 間隔で水温, 塩 分を測定した。海水試料は, 各測点の水深に応じて表層 から鉛直方向に $0 \mathrm{~m}, 2 \mathrm{~m}, 5 \mathrm{~m}, 10 \mathrm{~m}$ および海底から上 方 $1 \mathrm{~m}$ 層で採取した。海水試料の測定項目は, 懸濁粒子 濃度 $(\mathrm{SS})$, 懸濁態有機炭素 $(\mathrm{POC})$, おょび POCの 炭素安定同位体比 $\left(\mathrm{d}^{13} \mathrm{C}\right)$ とした。

懸濁粒子用に採水したサンプルは，それぞれ $500 \mathrm{~mL}$ の海水サンプルを, $450^{\circ} \mathrm{C} に て 4$ 時間強熱したガラス フィルター (GF/F, Whatman $0.7 \mu \mathrm{m})$ で吸引濾過した 後, フィルターをアルミホイルで包んで涷結保存した。 その後, 凍結乾燥し, 重量を計測した。重量測定後, そ れぞれのフィルターは, 塩酸を用いて無機炭酸塩を除 き, 凍結乾燥後, 元素分析計 $(\mathrm{NC}-2500)$ で POC 濃度 を測定し，元素分析計に接続された質量分析計 (DELTA plus, Thermo Fisher Scientific) で $\mathrm{d}^{13} \mathrm{C}$ を測 定した。 $\mathrm{d}^{13} \mathrm{C}$ は，以下の式を用いて示した。

$\mathrm{d}^{13} \mathrm{C}=\left[\mathrm{R}_{\text {sample }} / \mathrm{R}_{\text {standard }}-1\right]^{*} 1000(\%)$

ここで, $\mathrm{R}$ は同位体比 $\left({ }^{13} \mathrm{C} /{ }^{12} \mathrm{C}\right.$ を)を示し, Sample は測定試料の同位体比, Standard は標準物質 (PDB) を示す。

\section{3 データ解析}

淡水の割合 $(\mathrm{FW})$ は, 塩分 $(\mathrm{S})$ を基準として以下 の式により算出した。

$\mathrm{FW}=\left(\mathrm{S}_{\text {sample }}-\mathrm{S}_{\text {seawater }}\right) / \mathrm{S}_{\text {seawater }}$

ここで, sample および seawater はそれぞれ実測值お よび今回の調査時における最大值（31.1）を示す。

諫早湾内における物質量を算出するために, 諫早湾 
(面積 $65 \mathrm{~km}^{2}$ ) 9 分割し, 1 調査定点の影響範囲を $7.2 \mathrm{~km}^{2}$ とした。調査当日, 排水が行われた北門近傍の 調査定点（Stn B1-1）に打ける淡水，SS および POCの 現存量は各層の実測値から積算値を算出し, 影響範囲 $\left(7.2 \mathrm{~km}^{2}\right)$ を乗じて北門近傍における絶対量を算出した。 排水に伴う絶対量の増加量は, 排水前後の差分により算 出した。また，調整池の濃度と排水量を元にした懸濁物 排出量の理論值は, 排水量 $\left(2.3 \times 10^{6} \mathrm{~m}^{3}\right)$ に対して, 調整 池の SS 濃度（141 $\mathrm{mg} \mathrm{L}^{-1}$ ) おょび POC 濃度（5.8 mg $\left.\mathrm{L}^{-1}\right)$ を乗じて算出した。

調整池から排出された POC の寄与率 (Contribution) は, 炭素安定同位体比 $\left(\mathrm{d}^{13} \mathrm{C}\right)$ による 2 エンドメンバー のミキシングモデルを用いて，以下の式により推定し た。

Contribution $=\left(\mathrm{d}^{13} \mathrm{C}_{\text {sample }}-\mathrm{d}^{13} \mathrm{C}_{\text {sea }}\right) /\left(\mathrm{d}^{13} \mathrm{C}_{\text {res }}-\mathrm{d}^{13} \mathrm{C}_{\text {sea }}\right)$

ここで, $\mathrm{d}^{13} \mathrm{C}$ sample はそれぞれのサンプル， $\mathrm{d}^{13} \mathrm{C}$ sea は 今回の調査時における最大值 $(-18.8 \%), \mathrm{d}^{13} \mathrm{C}_{\mathrm{res}}$ は調 整池の採水試料の同位体比 $(-25.7 \%$ ）とする。

\section{3. 結果}

\section{1 排水に伴う水質の変動}

潮受堤防北部排水門（以下，北門）から，9月 18 日 16 時頃に排水が行われ，その 1 時間後の 17 時の観測によ り諫早湾への排水が確認された（Fig. 4)。排水された 北門の周辺では, 淡水流入に伴う低塩分化が顕著であ り，一時的に表層水の塩分が 10.6 まで低下した（Fig. 4a)。鉛直断面図によると, Stn B1-1 における塩分は全 層で低下したものの, 底層の塩分は 25 と比較的高く, 塩分成層が形成された（Fig. $4 \mathrm{~b} ）$ 。排水から 3 時間経過 した後においても (19 時)，上げ潮への転流時であった ことから（Fig. 3)，低塩分水のパッチは移動すること もなく Stn B1-1のみで確認された（Fig. 4a)。この時 の鉛直的な特徴として, Stn B1-1の底層水の塩分は 28 程度にまで上昇したが，強固な塩分成層は保持されたま まであった（Fig. 4b）。排水から 21 時間後（19日 13 時), 湾内には低塩分水が残って㧍らず，全域で塩分が 29 程度となり, 排水前と同程度になった。

懸濁粒子（SS）濃度についても，17 時の観測では排水

(a)

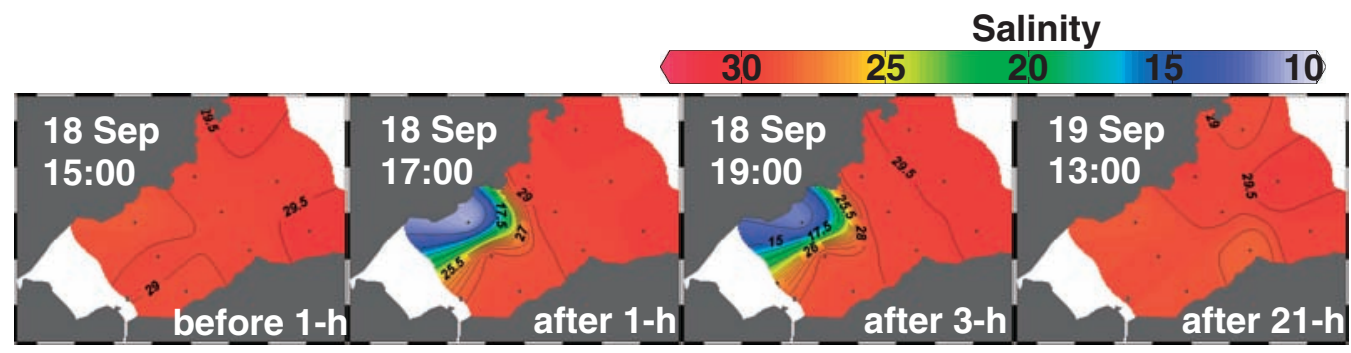

(b)

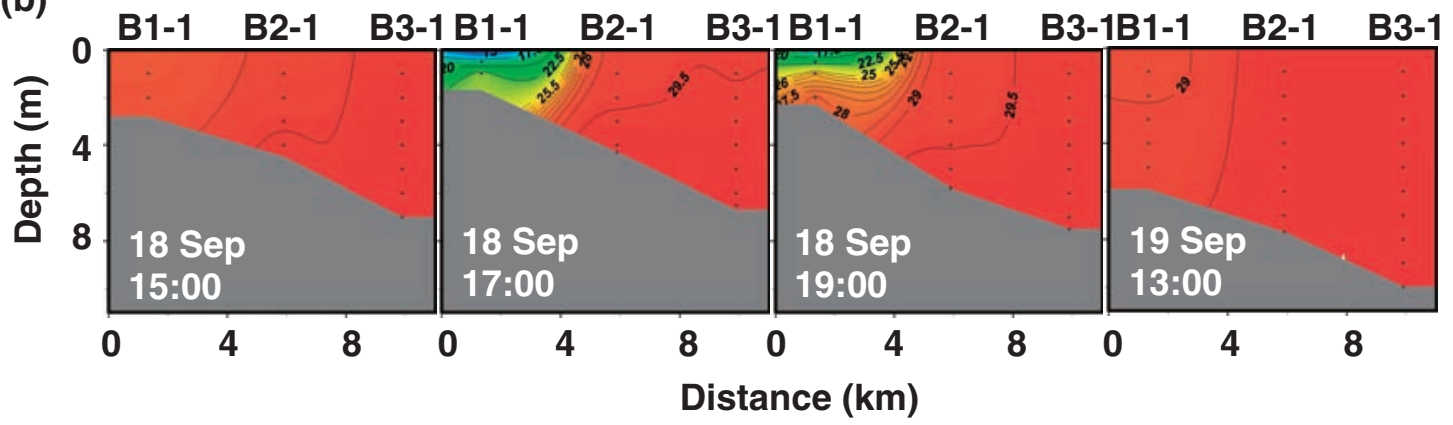

Fig. 4. (a) Spatial distribution and (b) vertical distribution along the north transect line of salinity at each sampling instance. 
(a)

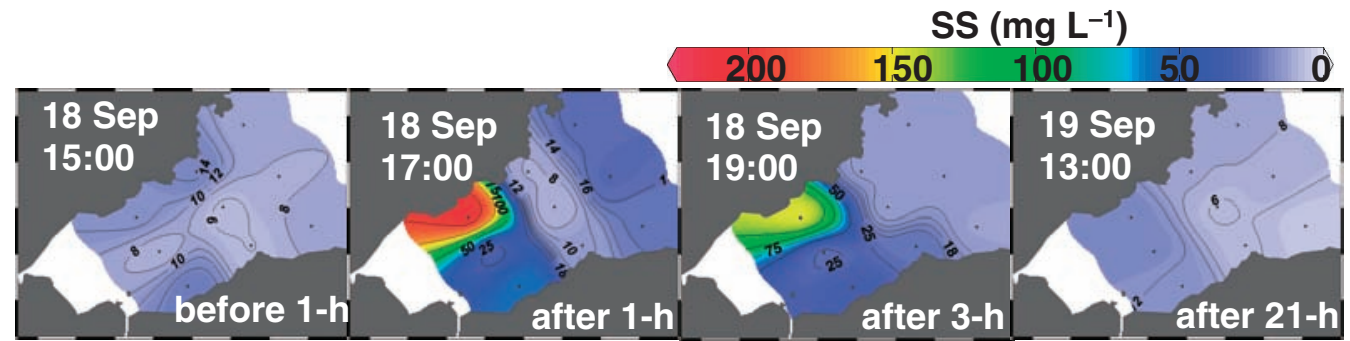

(b)

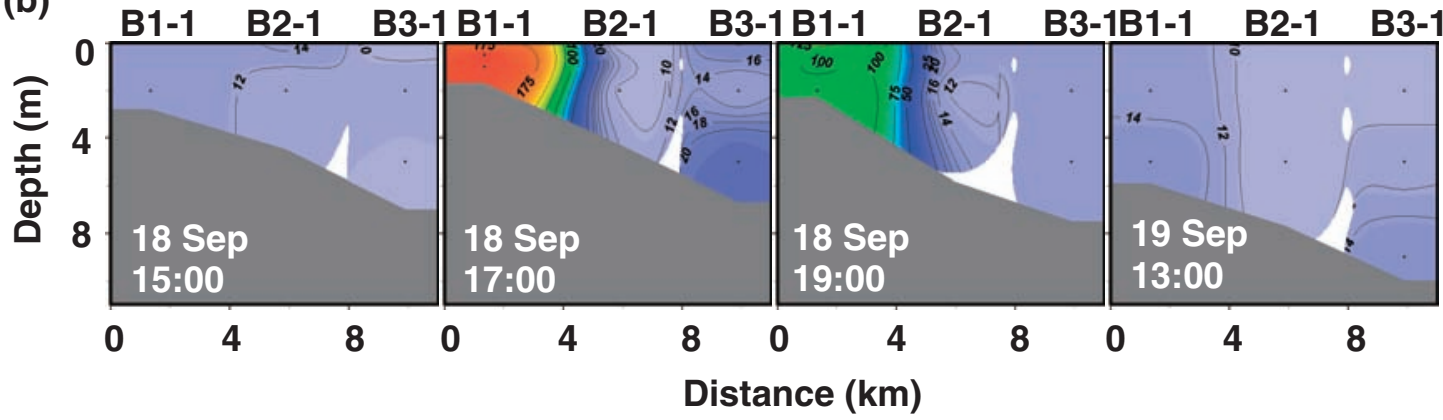

Fig. 5. (a) Spatial distribution and (b) vertical distribution along the north transect line of SS concentration at each sampling instance.

に伴い北門近傍（Stn B1-1）において $170 \mathrm{mg} \mathrm{L}^{-1}$ に達 し（Fig. 5a），排水から 3 時間後においても $151 \mathrm{mg} \mathrm{L}^{-1}$ と排水の影響を強く反映し, 影響範囲は北門近傍に限ら れていた。塩分との大きな違いは，表層から底層まで全 層で均一な点である (Fig. $5 \mathrm{~b})$ 。排水から 21 時間後 (19 日 13 時)，湾内の $\mathrm{SS}$ 濃度は全域で $10 \sim 14 \mathrm{mg} \mathrm{L}^{-1}$ の 範囲内に収まり，排水前と同程度となった。

排水直後に打ける懸濁態有機炭素 (POC) 濃度の分 布は, SS と同様に北門近傍で高く（最大 $6.5 \mathrm{mg} \mathrm{L}^{-1}$ ), 全層で均一であった（Fig. 6a, b)。さらに，排水から 21 時間後に抢いて, 排水前と同程度の低濃度になった 点も同様の傾向であった。これに対して, 排水から 3 時 間後の POC 濃度は, 北門近傍における最大值でも $1 \mathrm{mg} \mathrm{L}^{-1}$ と, 排水直後の 2 割程度に至った（Fig. 6a）。

懸濁態有機炭素の炭素安定同位体比 $\left(\mathrm{d}^{13} \mathrm{C}\right)$ について は, 排水の 1 時間前（18 日 15 時）の時点で, 湾奥部の 定点（Stn B1-1 B1-3）で-21\%o程度と，湾口部の定 点 $(-18 \sim-20 \%$ ) に比べて低い值を示した（Fig. $7 \mathrm{a})$ 。排水に伴い，北門近傍の定点の全層で $\mathrm{d}^{13} \mathrm{C}$ は - $24 \%$ \%まで低下した（Fig. 7a, b)。 $\mathrm{d}^{13} \mathrm{C}$ の時間変化は $\mathrm{POC}$ 濃度と異なり, 排水から 3 時間後においても, 北
門の近傍では $\mathrm{d}^{13} \mathrm{C}$ が低く, 調整池 $(-25.6 \%)$ の影響 を強く反映した。この時の鉛直的な特徵は, 塩分の分布 と類似して抢り (Fig. 4b), 塩水の遡上により底層では $\mathrm{d}^{13} \mathrm{C}$ が上昇する傾向が示された。

Fig. 8 は, 2 エンドメンバーのミキシングモデルによ り算出した調整池由来の POC の寄与率を示す。調整池 由来の有機物の寄与率は, 排水直後で 0.6 程度であった ものの, 3 時間後に最大となる 0.9 を北門近傍の表層で 記録し，その他のパラメーターとは異なるパターンを示 した。また，排水の影響が弱い時間帯（例えば排水前） でさえも, 諫早湾の奥部においては寄与率が 0.2 以上で あった。

\section{2 北門近傍における絶対量の時間変化と湾全域に対 する量的な寄与}

北門近傍（Stn B1-1）における淡水量, SS 量, POC 量の時間変化を Fig. 9 に示す。全ての項目に共通した傾 向としては, 排水直後に絶対量が 3 から 10 倍に増加し た点である。淡水量および SS 量については，それぞれ 比較的高い值を維持していた一方で, POC 量について は排水から 3 時間後には排水前とほぼ同程度にまで減少 
した。また，排水の影響が直接的に反映されなかった時 間帯（18 日の 17 時, 19 時以外）については，潮位変動
と同調する傾向が示された。

SS およびPOC の濃度を元に算出した調整池からの排

(a)

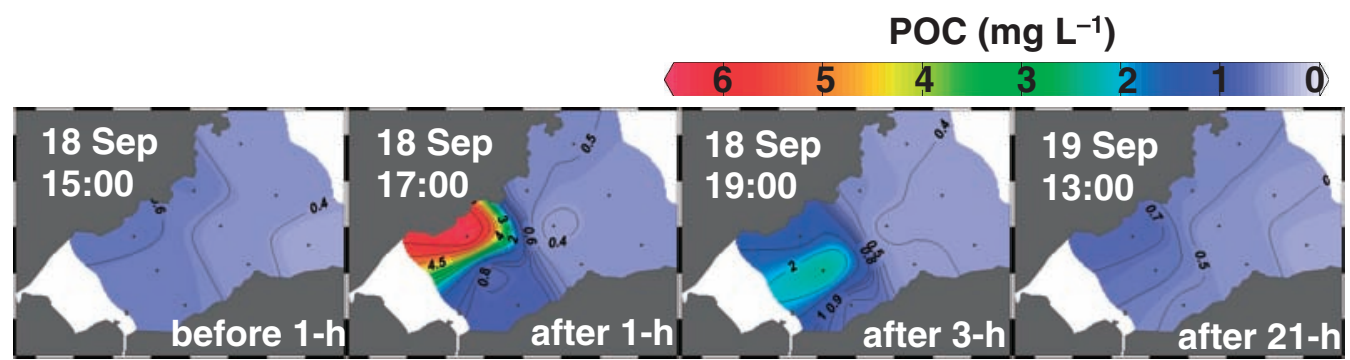

(b)

after $1-h$

after 3-h

after $\mathbf{2 1 - h}$

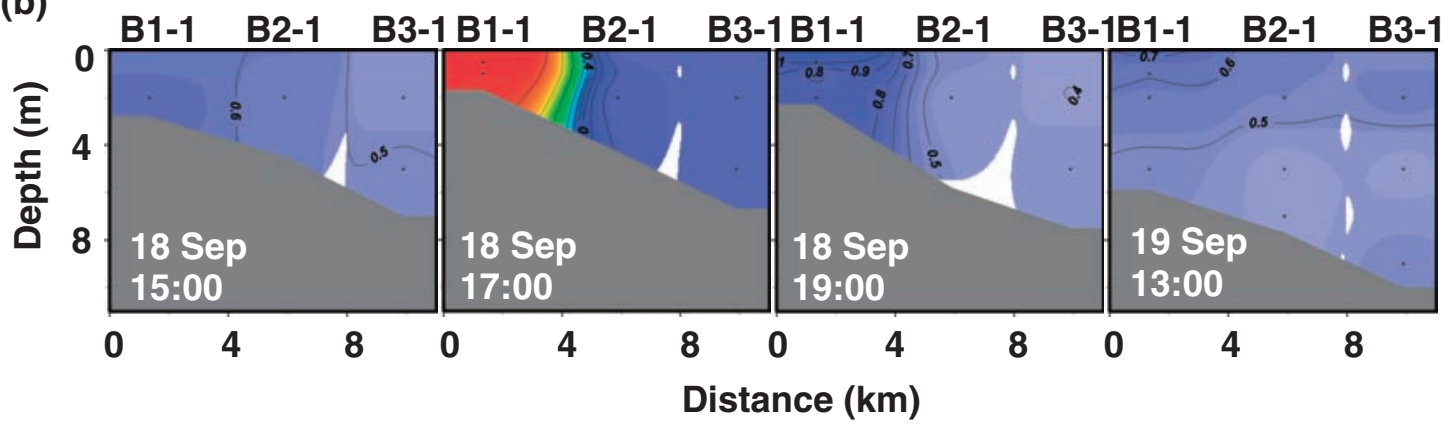

Fig. 6. (a) Spatial distribution and (b) vertical distribution along the north transect line of POC concentration at each sampling instance.

(a)

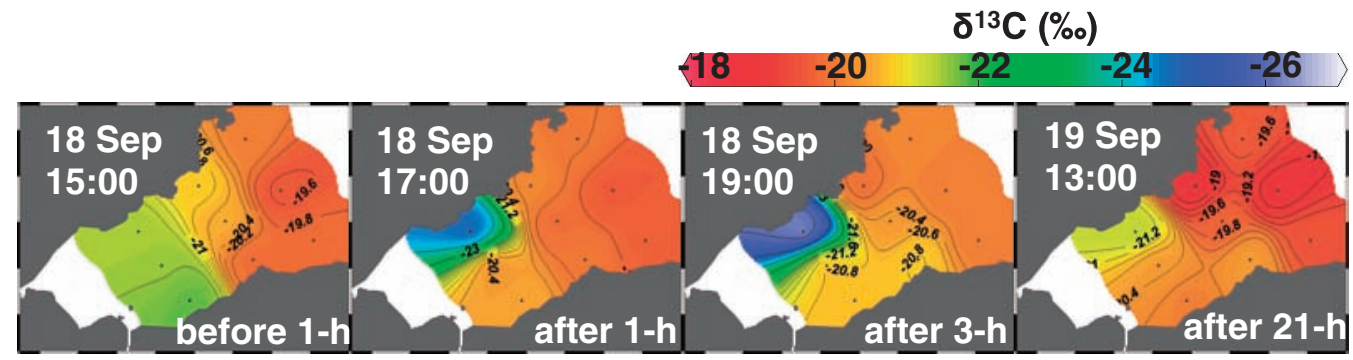

(b)

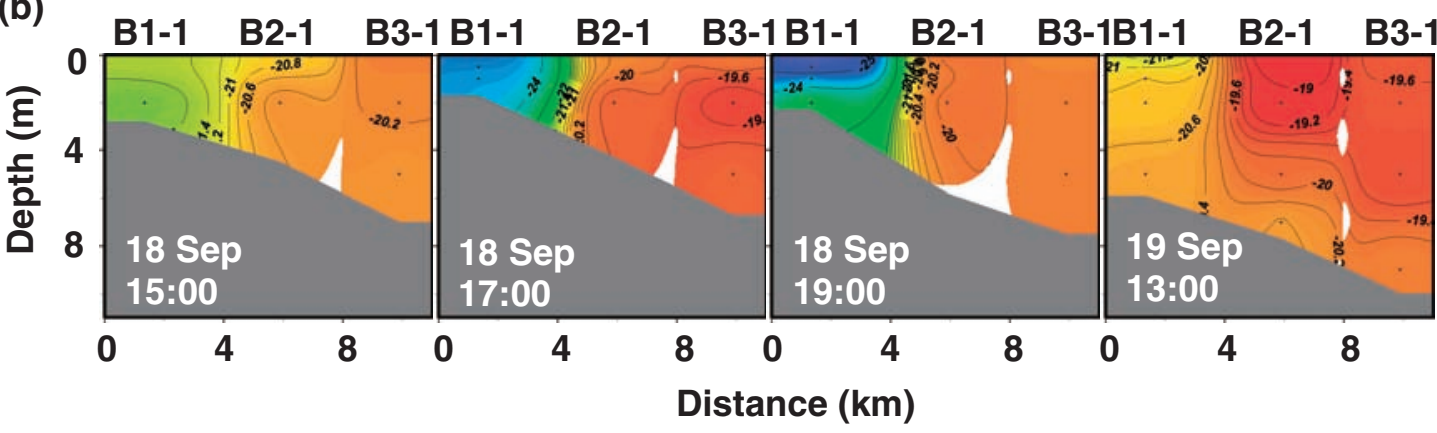

Fig. 7. (a) Spatial distribution and (b) vertical distribution along the north transect line of stable carbon isotope ratio of $\mathrm{POC}$ at each sampling instance. 
水量の理論值, 北門近傍における絶対量の増加量, およ び排水が直接影響していない時間带（18 日の 17 時, 19 時以外) における湾全体の絶対量の平均值を Table 1 に 示す。濃度を基準とした排水量の理論值については, $\mathrm{SS}$ および POC 量それぞれ $326 \times 10^{6} \mathrm{~g}$ ならびに $13.3 \times$ $10^{6} \mathrm{~g}$ となった。北門近傍における増加量について，淡 水量では $1.84 \times 10^{6} \mathrm{~m}^{3}$ と実際の排水量の 8 割程度であっ た一方，SS 量および POC 量についてはそれぞれ 2,386 $\times 10^{6} \mathrm{~g}$ ならびに $61.7 \times 10^{6} \mathrm{~g}$ に達し, 排水量の理論值に 対してそれぞれ 6 倍ならびに 3 倍となった。さらに，絶 対量の増加量は湾全体の絶対量の $26 \%$ （POC）および 39 \%（SS）に達した。

\section{4. 考察}

本研究では, 9 月 18 日の 16 時頃に排水が行われ，そ の 1 時間後の 17 時の観測時には諫早湾への排水の影響 が観測された（Fig. 4)。排水された北門の周辺では, 淡水流入に伴う低塩分化が顕著であり，一時的に表層水 の塩分が 10.6 まで低下した（Fig. 4)。同時に，北門近 傍の SS 濃度は最大で $170 \mathrm{mg} \mathrm{L}^{-1}$ に達し, POC につい
ても $6.45 \mathrm{mg} \mathrm{L}^{-1}$ に達した（Fig. 5 and 6)。排水から 3 時間後, 北門近傍の表層水は依然として塩分が 15 と低 い一方で, 水深 $2 \mathrm{~m}$ 層の塩分は 27 であり, 強固な塩分 成層が形成された。齋田ら (2010) は，排水門からの排 水の影響がない日の調査結果から, 諫早湾湾口部の北側 (本研究の D3-1 近辺) において調整池の中央ポンプから 排出されたと考えられる低塩分水（27 程度）のパッチ を検出したことから，下げ潮時に湾口部まで淡水が流出 することを示している。これに対して，南門からの排水 の挙動を漂流ブイにより追跡した研究では, 排水後 4 時 間程度までは目視可能な高濁度水のフロントを形成して いたが，海陸風の影響を受けて波高が増大したことによ り，フロントが目視で追跡できなくなったことが報告さ れている(多田ら，2010）。本研究では，排水された高 濁度水のパッチが下げ潮時に移流する時間帯（9月 19 日の 0 時〜 6 時頃) に観測していないため，懸濁粒子の 湾外への流出過程を詳細に記載することができない。し かしながら，排水から 21 時間後の 9 月 19 日 13 時には 全域で SS および POC 濃度が排水前と同程度になって いたことから，少なくともこの間にこれらの物質が水柱 から除去されたことは明らかである。

\section{(a)}

\section{Contribution of organic matter}

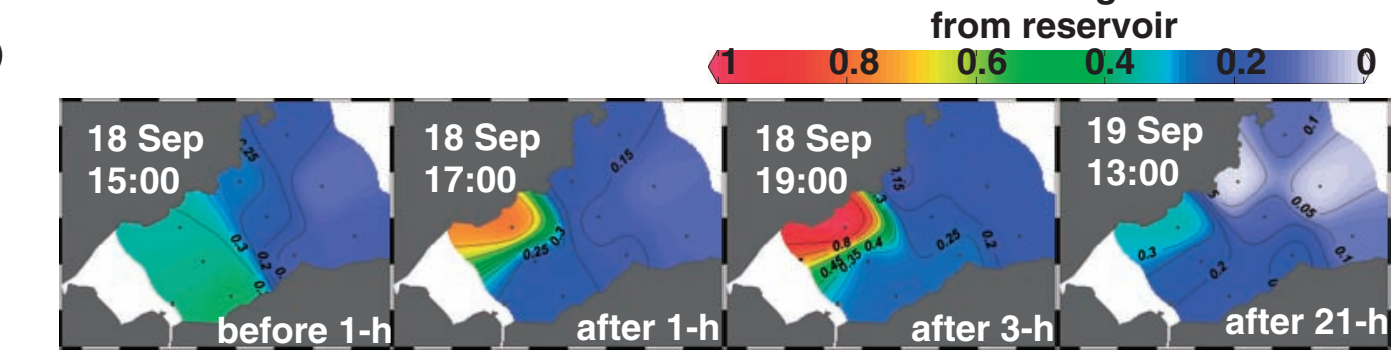

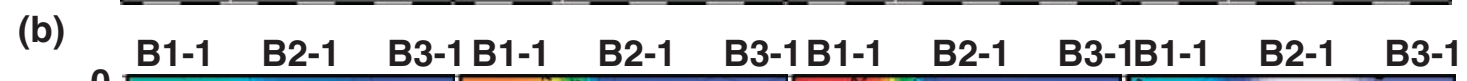

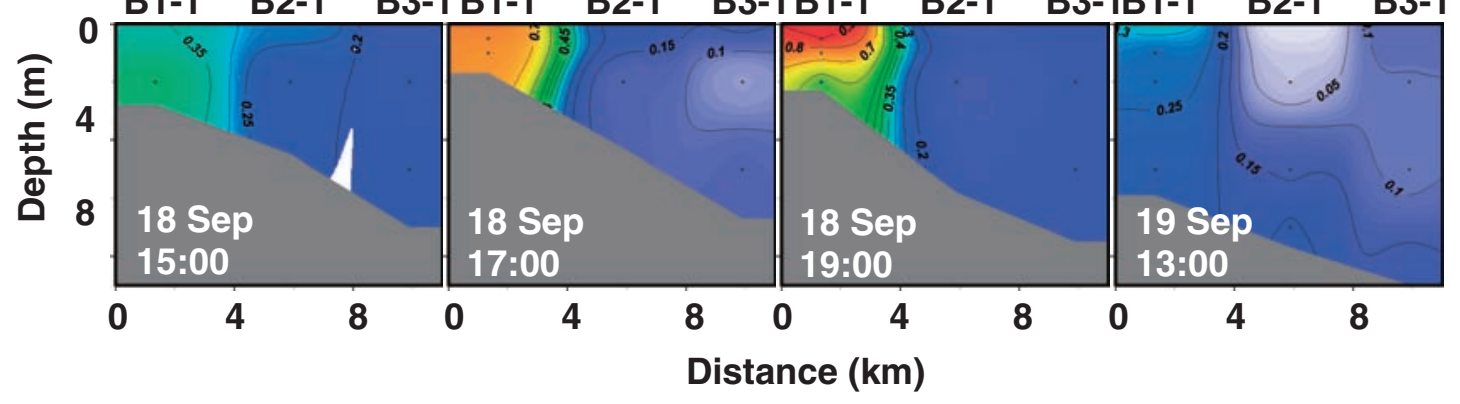

Fig. 8. (a) Spatial distribution and (b) vertical distribution along the north transect line of contribution of the organic matter derived from reservoir to POC at each sampling instance. 
Table 1. Comparison between the amount of discharge estimated by the concentration in the reclaimed land and the amount for in front of the north gate (Stn B1-1) and whole in Isahaya Bay.

\begin{tabular}{lrrr}
\hline & $\begin{array}{c}\text { Fresh water } \\
\left(10^{6} \mathrm{~m}^{3}\right)\end{array}$ & $\begin{array}{c}\text { SS } \\
\left(10^{6} \mathrm{~g}\right)\end{array}$ & $\begin{array}{c}\text { POC } \\
\left(10^{6} \mathrm{~g}\right)\end{array}$ \\
\hline \hline Discharge estimated by the concentration in the resorvior & 2.3 & 326 & 13.3 \\
Change of the amount in front of the North Gate & 1.84 & 2,386 & 61.7 \\
Mean amount whole in the bay without direct discharge & 28.5 & 5,425 & 207.8 \\
\hline
\end{tabular}

排水に伴う SS, POC の絶対量の変化を, 湾内におけ る絶対量の平均值と比較したところ (Table 1), SS は 4 割を占め, POC 量としても 3 割に達した。淡水の増加 量は調整池からの排水量 $\left(2.3 \times 10^{6} \mathrm{~m}^{3}\right.$, Fig. 1$)$ と同程 度であり, 排出量とよく一致していた。これに対して, 排水量に調整池の SS 濃度 $\left(141.7 \mathrm{mg} \mathrm{L}^{-1}\right)$ と POC 濃度 $\left(5.80 \mathrm{mg} \mathrm{L}^{-1}\right)$ を乗じて試算した排出量は, 北門近傍に おける SS および POC 増加量の 2 割程度に過ぎなかっ た (Table 1)。これは, 堆積物の再懸濁によって引き 起こされると考えられ, 水柱の SS および POC 増加量 の 8 割を占める結果となった。

調整池内部の䯚濁粒子は粒径が数 $\mu \mathrm{m}$ 程度の小型な粘 土鉱物であることから（佐々木, 2005), 沈降速度が遅 く水中に留まりやすいと考えられる。ここで沈降速度に 対してストークス則の適用可能な範囲として, レイノル ズ数 $\left[\mathrm{Re}=\mathrm{vd} / \mu, \mathrm{v}\right.$ は流速 $\left(\mathrm{cm} \mathrm{s}^{-1}\right), \mathrm{d}$ は粒径 $(\mathrm{cm})$, $\mu$ は海水の動粘性係数 $\left.\left(\mathrm{cm}^{2} \mathrm{~s}^{-1}\right)\right]$ が 0.5 以下の場合, 粒子の形状に関わらずストークス則が成り立つ（Mann and Lazier, 2006)。すなわち, $\operatorname{Re}=\mathrm{vd} / \mu \leqq 0.05$ の場 合 (海水の動粘係数は $0.01049 \mathrm{~cm}^{2} \mathrm{~s}^{-1}$ ), 懸濁粒子の沈 降速度は, ストークスの最終速度を vs $\left(\mathrm{cm} \mathrm{s}^{-1}\right)$ とし て,

$$
\text { vs }=(1 / 18) \operatorname{gd}^{2}\left(\rho_{\text {particle }}-\rho_{\text {water }}\right) / \mu
$$

で表される。ただし，g は重力定数， $\rho_{\text {particle }}$ および $\rho_{\text {water }}$ はそれぞれ粒子ならびに海水の密度を示す。粒子の比重 として無機鉱物の代表值をカオリンの比重である $2.6 \mathrm{~g}$ $\mathrm{cm}^{-3}$ とし, 海水の密度を $1.024 \mathrm{~g} \mathrm{~cm}^{-3}\left(20^{\circ} \mathrm{C}\right)$ とした
場合, 懸濁粒子径に対して粒子が水中を $1 \mathrm{~m}$ 沈降するた めに要する時間の変化を Fig. 10 に示す。本研究では, 少なくとも排水後の 3 時間, 粒子が懸濁していた（Fig. 5)。この観測值とストークスの最終沈降速度を照らし 合わせると（Fig. 10), 粒子径が $10 \mu \mathrm{m}$ 未満であれば 粒子が 3 時間懸濁し続けることが可能であることがわか る。調整池の堆積物の中央粒径值は $4 \mu \mathrm{m}$ 程度であり (梅原, 未発表), 諫早湾奥部においても堆積物の細粒化 が進行しており，その中央粒径は $9.6 \mu \mathrm{m}$ 程度である (李・松永, 2010)。これらの結果を総合すると, 排水直 後の諫早湾奥部は水深が $1 \mathrm{~m}$ と浅く, 干潮時であること から半止水的な状態であっても, 調整池の堆積物由来の 粒子であれば，約 20 時間懸濁することが可能となる (Fig. 10)。そのため, 排水後 3 時間経過しても, SS の 濃度（Fig. 5) および絶対量（Fig. 9b）に大きな変化が 見られなかったと考元られる。

排水直後には, POC の増加量も湾全体の平均現存量 の約 4 割を占めた一方で (Table 1), 排水の 3 時間後 には，濃度および現存量ともに排水前と同程度にまで低 下ならびに減少した（Figs. 6 and 9)。POC が水柱から 除去される要因としては, 移流, 分解および沈降が可能 性として挙げられる。この間における移流については, 排水後には上げ潮に転じたことから湾外への流出は起き ておらず，調整池由来の POC については水平的なパッ チの移動が見られないことから (Fig. 7), その可能性 は低いと言える。分解については, 有明海西部海域の高 濁度水中において, SS 濃度が $100 \mathrm{mg} \mathrm{L}^{-1}$ の時の酸素 消費速度が $0.3 \mathrm{mg} \mathrm{O} 2 \mathrm{~L}^{-1} \mathrm{~h}^{-1}$ に達することが室内実験 により報告されている（阿部ら，2003）。これが全て好 
気的に分解されているとすれば, 炭素等量で $0.11 \mathrm{mg} \mathrm{C}$ $\mathrm{L}^{-1} \mathrm{~h}^{-1}$ となる。この值を本研究において適用すると, 本研究で得られた POCの最高值 $\left(6.5 \mathrm{mg} \mathrm{L}^{-1}\right)$ の $2 \%$ 未満に過ぎないことになる。そのため, 分解の卓越によ り POC 濃度が低下したことも考えにくい。沈降による
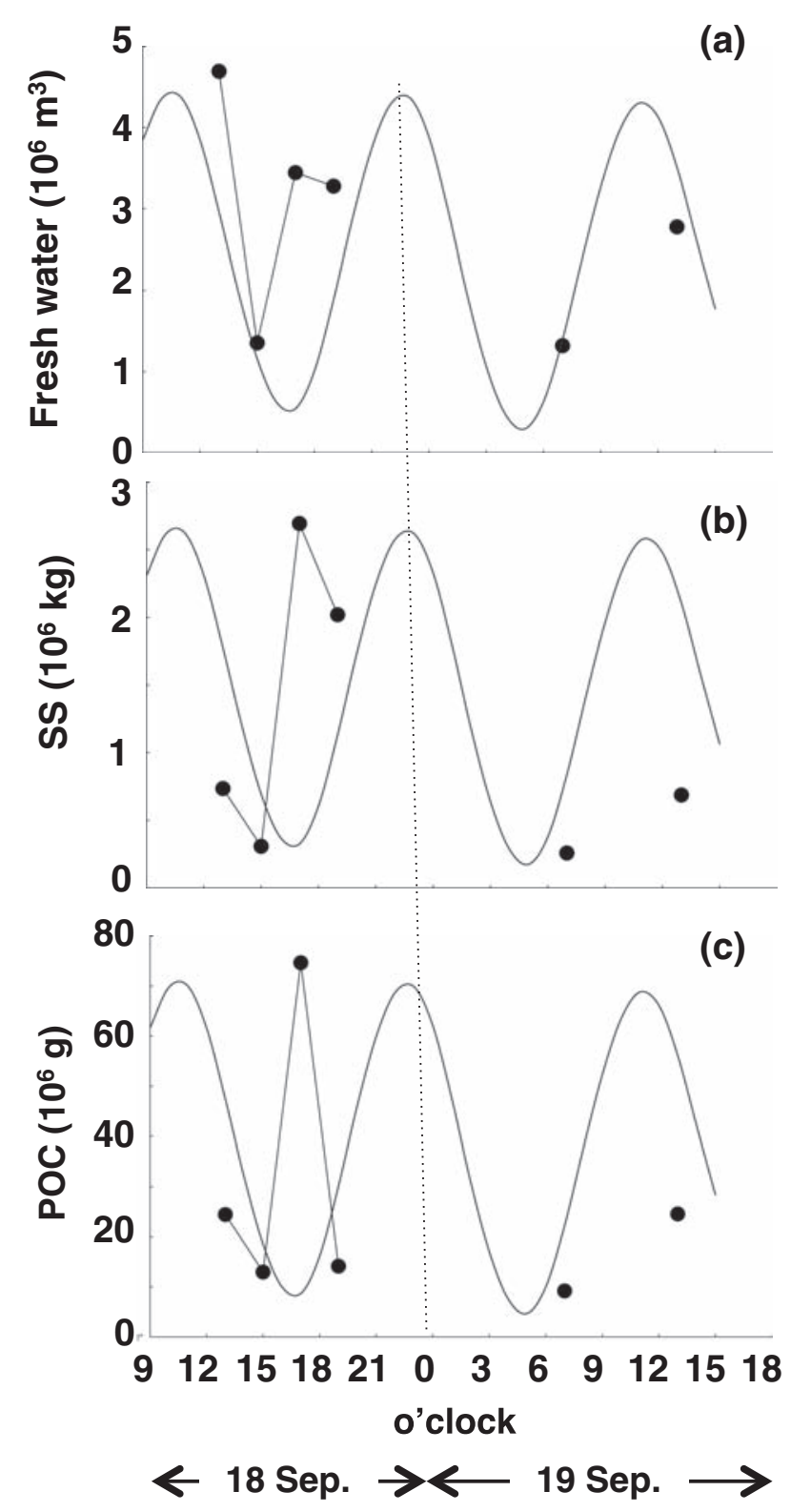

Fig. 9. Time series variations of amount of (a) fresh water, (b) SS, and (c) POC at the front of north gate (Stn B1-1). Curved lines indicate the relative tidal height during the sampling period.
POC の除去が主であるとすると, 本研究では排水から 3 時間以内に POC の約 8 割が沈降したこととなる (Fig. 6)。これは, 排水に伴い供給された有機物の約 8 割の 粒子が $10 \mu \mathrm{m}$ より大きければ可能となる (Fig. 10)。 これらのことを総合すると, POCの粒径分布は $10 \mu \mathrm{m}$ 以上の大型粒子と, SS と同様の $10 \mu \mathrm{m}$ 未満の小型粒子 の二蜂型であることが想定される。本研究域のように塩 分が大きく変化する条件下では, 電気的な凝集による粒 子径の増大と沈降速度の上昇が予測される（例えば，内 山ら, 2011, 一見ら, 2012)。今後の課題として, 排水時 における凝集作用の寄与について検討する必要がある。

北門近傍における有機物の濃度 (POC) に対して有 機物の質 $\left(\mathrm{d}^{13} \mathrm{C}\right)$ は, 排水から 3 時間後では排水直後に 比べて調整池由来の有機物による寄与率がほぼ $100 \%$ と なった（Fig. 8)。上述の POC と SS の時間変化の違い に関する考察から, 排水から 3 時間経過した段階で水柱 に懸濁しているPOC は全体の約 2 割に相当し, その粒 径が $10 \mu \mathrm{m}$ 以下の小型粒子である可能性が高いと考え られる。この SS 抢よび POC の湾外への流出過程につ いては詳細な検討が必要であるものの, 粒子径をもとに 懸濁時間を考慮すると, 調整池由来の SS および POC は水深 $1 \mathrm{~m}$ を沈降するだけでさえも, $3 \sim 20$ 時間を要 することとなり，下げ潮時に湾外へと流出する可能性が 高い。この結果として, 排水から 21 時間後には塩分や SS, POC に関しては湾奥部を残して調整池からの影響が 見られなくなったと考えられる。

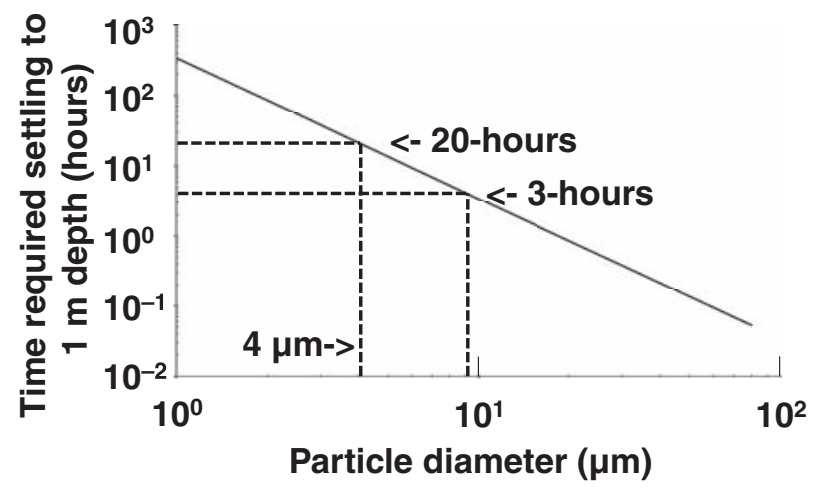

Fig. 10. Relationship between the particle diameter and time required for the particle to settle in the $1 \mathrm{~m}$ of water column based on Stokes' Law. 


\section{5. 結論}

本研究では，面的観測を実施することにより，調整池 からの排水を捉えることに成功した。理論的に推測され た調整池からの SS 抢よび POC 排出量に対して, 排水 門近傍の増加量はそれぞれ 4 倍ならびに 6 倍に至った。 この理由としては, 排水に伴う堆積物の再懸濁の可能性 が示された。SSについては, 懸濁時間が少なくとも 3 時間継続したことから, $10 \mu \mathrm{m}$ 以下の細かな粒子が主で ある可能性が示唆された。これに対して, POCについ ては，排水から 3 時間後には約 8 割が沈降したことか ら, 粒径が $10 \mu \mathrm{m}$ 以上の有機物が主体であった可能性 が高い。POCの量としては, 排水直後の 2 割程度にま で減少したものの，北門近傍におけるPOCの 8 から 10 割が調整池由来の有機物であり, これらの粒子は水柱を $1 \mathrm{~m}$ 沈降するために $3 \sim 20$ 時間程度を要する。このこ とを踏まえると，これらの粒子が下げ潮時には湾外へと 流出する可能性が高いと考元られる。

\section{謝 辞}

本研究の一部は，三井物産環境基金（代表者：堤裕昭） 「豊饒の沿岸閉鎖性海域で発生する環境異変の原因究明 と沿岸生態系回復策の提示（助成番号：R09-B118）」, 科学研究費補助金（基盤研究 $\mathrm{B}$ ，代表者：堤裕昭）「有明 海奥部海域に打ける貧酸素水の発生メカニズム（課題番 号：22310012）」，科学研究費補助金（基盤研究 B，代表 者：堤裕昭）「諫早湾における海水流動の変化が有明海奥 部海域の環境と生態系に及ぼす影響の評価（課題番号： 25281031)」, 笹川科学研究助成（代表者：梅原亮）「諫 早湾干拓調整池における有毒アオコ発生システムを含む 物質循環の解明と開門による塩分上昇の影響（研究番 号：24-718)」の助成を受けて実施された。調査を実施 するにあたって，小長井漁業共同組合の松永氏，田實 氏, 有明町漁業協同組合の松本氏には調査船を提供して 頂いた。熊本県立大学海洋生態学研究室の高田みはる, 野村龍之介, 折田亮, 松本麻里, 竹中理佐, 田崎克, 中 野由郁, 橋口由衣, 村中志帆, おょび九州大学環境流体 力学研究室の久野彰大の諸氏には野外観測およびサンプ ルの一次処理に際して全面的な協力を得た。2名の匿名
査読者からは本稿に対して的確な助言を頂いた。この場 を借りて，感謝の意を表す。

\section{References}

阿部淳, 松永信博, 児玉真央, 徳永貴久, 安田秀一 (2003) : 有明海西部 海域に抢ける高濁度層の形成と酸素消費過程。海岸工学論文集, 50, 966-970.

一見和彦, 濱口佳奈子, 山本昭憲, 多田邦尚, 門谷茂 $(2011)$ : 新川・春 日川河口干潟域（瀬戸内海備讃瀬戸）に打けるリンの収支. 沿岸海 洋研究, 48, 167-178.

李洪源，松永信博（2010）：諫早湾の底泥環境特性。土木学会論文集 B, 66. $321-334$.

Mann, K. H. and J. R. N. Lazier (2006) : Dynamics of marine ecosystems : biological-physical interactions in the ocean. Blackwell Publishing, Victoria., 496 pp.

中村武弘, 矢野真一郎, 多田彰秀, 野中寛之, 亀井雄一（2002）：諫早湾 湾口部に抢ける流況の現地観測。海岸工学論文集, 49, 396-400.

齋田倫範, 田井明, 橋本彰博, 大串浩一郎, 多田彰秀, 松永信博, 小松 利光 $(2010)$ ：諫早湾内に打ける低塩分水の挙動に関する現地観測。 水工学論文集, 54, 1543-1548.

齋田倫範，矢野真一郎，田井明，小松利光 (2006)：夏季小潮期の現地観 測による諫早湾の海水交換に関する検討。海岸工学論文集, $\mathbf{5 3}, 336$ -340 .

佐藤正典（2000）：有明海の生きものたち：干潟・河口域の生物多様性 株式会社海遊社，東京， $396 \mathrm{pp}$.

佐々木克之 (2005)：2 章 開発行為, p. 39-48. 有明海の生態系再生をめ ざして, (編) 日本海洋学会, 恒星社厚生閣, 東京.

田井明, 小松利光 (2013) : 諫早湾奥からの物質輸送過程と有明海異変に 関する考察．土木学会論文集 B1（水工学）, 69, I_1375-I_1380.

田井明, 扇塚修平, 齋田倫範, 多田彰秀, 堤裕昭, 小松利光 (2012)：諫 早湾口北部周辺の流動特性について。土木学会論文集 B1（水工学）, 68, I_1687-I_1692.

多田彰秀, 竹八内健太, 染矢真作, 坂井伸一, 水沼道博, 中村武弘, 坪 野孝樹（2007）：DBF 海洋レーダ観測に基づく諫早湾湾口部の表層 流動特性について。海岸工学論文集, 54, 391-395.

多田彰秀，中村康裕，阿部和也，田井明，鈴木誠二，中村武弘（2010）： 淡水流入が諫早湾の水質動態に及ぼす影響について。 土木学会論文 集 B2（海岸工学）特集号, 66, 366-370.

手塚公裕，片野俊也，濱田孝治，加端，日野剛徳，速水祐一，伊藤祐二， 大串浩一郎 (2012)：諫早湾抢よび隣接する調整池における底質の栄 養塩分布. 海の研究, 21, 69-81.

坪野孝樹，吉井匠，松山昌史，坂井伸一，多田彰秀（2009）：海陸風と海 洋レーダで観測された諫早湾口周辺の日周潮流速. 土木学会論文集 B2 (海岸工学) 特集号, 65, 401-405.

堤裕昭, 岡村絵美子, 小川満代, 高橋徹, 山口一岩, 門谷茂, 小橋乃子, 安達貴浩, 小松利光 (2003) : 有明海奥部海域に抒ける近年の貧酸素 水塊抢よび赤潮発生と海洋構造の関係。海の研究, 12, 291-305。

堤裕昭，堤彩，高松篤志，木村千寿子，永田紗矢香，佃政則，小森田智 大, 高橋徹, 門谷茂 (2007)：有明海奥部における夏季の貧酸素水発 生域の拡大とそのメカニズム。海の研究, 16, 183-202.

内山卓也, 山本浩一, 古谷貴子, 横山勝英, 関根雅彦, 濱田孝治 （2012）：フロックカメラを用いた筑後川感潮域における懸濁物質の 沈降特性に関する研究．土木学会論文集 B2 (海岸工学), 67, I_881 
-I_885.

Umehara, A., H. Tsutsumi and T. Takahashi (2012) : Blooming of Microcystis aeruginosa in the reservoir of the reclaimed land and discharge of microcystins to Isahaya Bay (Japan). Environ. Sci. Pollut. Res., 19, 3257-3267. 


\title{
Short-term variation of high-turbidity water discharged from a reservoir of reclaimed land onto Isahaya Bay, Kyushu, Japan
}

\author{
Tomohiro Komorita ${ }^{1}$, Akira Umehara ${ }^{1}$, Akira Tai ${ }^{2}$, \\ Tohru Takahashi ${ }^{3}$, Hiroaki Tsutsumi ${ }^{1}$
}

\begin{abstract}
We determined short-term variation of water discharged onto a bay system (Isahaya Bay, Japan) by conducting a high-resolution field survey at nine sampling stations from September 18 to 19, 2012. The amounts of suspended solids (SS) and particulate organic carbon (POC) discharged in water from the reservoir multiplied by the amount of discharge from the reservoir and the concentrations of both SS and POC in reservoir were estimated as $326 \times 10^{6}$ and $3.3 \times 10^{6} \mathrm{~g}$, respectively. These discharge amounts accounted for only $16 \%$ and $25 \%$ of the change of the amount in front of the north gate. Thus, resuspension should occur for particulate matter from the reservoir sediment and/or from in front of the north gate. According to Stokes' Law, the main particle diameter should be less than 10 $\mu \mathrm{m}$ for SS, and more than $10 \mu \mathrm{m}$ for POC, respectively, on the basis of the time series variation for SS and POC. Three hours after the discharge, POC concentration in front of the north gate had declined at the same order as before the discharge; however, the POC in the reservoir accounted for a high proportion (from $80 \%$ to $100 \%$ ) of the POC in front of the north gate. Part of the particulate organic matter from the reservoir must therefore flow out from Isahaya bay to Ariake Bay.
\end{abstract}

Key words : discharged water, high-turbidity, Isahaya Bay, suspended solids (SS), particulate organic carbon (POC)

(Corresponding author's e-mail address: komorita@pu-kumamoto.ac.jp)

(Received 23 May 2013; accepted 30 July 2013)

(Copyright by the Oceanographic Society of Japan, 2014)

\footnotetext{
1 Faculty of Environmental and Symbiotic Science, Prefectural University of Kumamoto, 3-1-100

Tsukide, Kumamoto 862-8502, Japan

2 Institute for Advanced Study, Kyushu University, 6-10-1 Hakozaki, Higashi-ku, Fukuoka, 812-8581, Japan

3 Department of Medical Technology, Kumamoto Health Science University, 325 Izumi-machi, Kumamoto 861-5598
} 